\title{
Corporate brand identity measurement - an application to the services sector
}

\author{
Teresa Barros* \\ Department of Business Sciences, \\ Porto Polytechnic-CIICESI, ESTGF, \\ Rua do Curral - Margaride, 4610-156 Felgueiras, Portugal \\ Email: mtb@estgf.ipp.pt \\ *Corresponding author
}

\section{F. Vitorino Martins}

Department of Management

Faculty of Economics,

University of Porto,

Rua Dr. Roberto Frias, 4200-464 Porto, Portugal

Email: vmartins@fep.up.pt

\section{Hortênsia Gouveia Barandas}

\author{
Faculty of Economics, \\ University of Porto, \\ Rua Dr. Roberto Frias, 4200-464 Porto, Portugal \\ Email: barandas@fep.up.pt
}

\begin{abstract}
Authors commonly agree that the identity of a brand is internally connected with staff and externally connected with the consumers and the rest of the stakeholders. Brand management studies are much focused on the external part, mainly on consumers. This research follows a different agenda exploring the brand identity dimensions by measuring the brand identity prism developed by Kapferer, both internally and externally. The measurement of brand identity is scarce in brand management literature. A reliable, valid and unique brand identity scale that empirically establishes the construct's dimensionality has yet to be developed in a highly consumer involvement context. This paper reports the findings of a research conducted at 235 engineering higher education students. Data were analysed using confirmatory factor analysis. Findings reveal that the brand identity prism is moderated by brand culture. This research also gave important insights regarding the theory proposed by Kapferer regarding the external brand identity.
\end{abstract}

Keywords: corporate brand identity; brand management; brand culture; brand co-creation; consumer involvement; corporate brands; higher education; scale development; services sector.

Reference to this paper should be made as follows: Barros, T., Martins, F.V. and Barandas, H.G. (2016) 'Corporate brand identity measurement an application to the services sector', Int. J. Innovation and Learning, Vol. 20, No. 2, pp.214-231. 
Biographical notes: Teresa Barros is a full-time Lecturer in Porto Polytechnic in ESTGF where she is responsible for courses and for supervising theses in the master of management and internationalisation of companies and in the Master of Project Management. She is also responsible for courses in the Bachelor degree of Business Science. She holds a PhD in Business Science - Marketing area. She is a usual attendant of conferences and special interest groups focused in branding like academy of marketing conference (special interest group in brand, identity and corporate reputation), and thought leaders in brand management, since 2004.

F. Vitorino Martins is a Senior Lecturer at Faculty of Economics of Porto University. $\mathrm{He}$ is a $\mathrm{PhD}$ in Econometrics. $\mathrm{He}$ is a regular author in econometrics related with marketing and finance.

Hortênsia Gouveia Barandas is a Senior Lecturer at Faculty of Economics of Porto University. She is also a consultant in international marketing. She is a $\mathrm{PhD}$ in Management. Her interests are related with international marketing, branding and relationship management and consumer behaviour.

This paper is a revised and expanded version of a paper entitled 'Corporate brand identity measurement in higher education' presented at MakeLearn and TIIM 2015, Bari, 17-29 May 2015.

\section{Introduction}

Research in identity is largely conceptual, e.g., Kapferer (1986, 2008), Balmer (1998), Balmer and Soenen (1999), Cornelissen et al. (2001), de Chernatony (1999), Meleware (2003) and Silveira et al. (2013). Valuable exceptions exist regarding corporate identity studies, e.g., Simões et al. (2005) and Suvatjis and de Chernatony (2005).

Having its roots in corporate identity, brand identity is studied by researchers producing significant number of conceptual frameworks, e.g., Aaker (1996), Burmann and Riley (2009), de Chernatony (1999), Upshaw (1995), Kapferer (1986, 2008, 2012), Semprini (2006) and Silveira et al. (2013). Although they produce very relevant discussions, conceptual frameworks are more often than not difficult to interpret and manage by brand managers. Apart from, Coleman et al. (2011) who studied the dimensions of brand identity applied to the UK IT services, existing work falls short of developing a fully articulated measurement of brand identity. This came about as an opportunity to measure the brand identity of corporate brands. Therefore, that became the aim of this research.

As it is not our intention to develop a new corporate brand identity framework, but to measure it, we use the conceptual framework developed by Kapferer $(1986,2008,2012)$ and applied it to the services sector, namely to higher education, a sector recognised by having a highly consumer involvement.

It is suggested by de Chernatony and Segal-Horn (2001) that the unique characteristics of the services sector: intangibility, inseparability of production and consumption, heterogeneity of quality, and perish ability, demand the use of different models from the classical ones. They claim that staff plays "an important role in services branding, influencing brand quality and brand values through interactions they have with 
consumers" (p.665). The services sector deals with highly involved potential consumers that are active looking for information in order to decide.

This paper also endeavours to give policy advice to general managers and to those having responsibility in service brands, for it is distinctive in that it:

- contributes to the fulfilment of a gap in the literature of brand identity management by producing a measurement of the concept of corporate brand identity developed by Kapferer $(1986,2008,2012)$

- integrates several concepts in literature that are related with brand identity by adapting and creating new scales connected to the dimensions of corporate brand identity in a highly consumer involvement context

- adopts the concept of students as particular stakeholders that transcend the internal/external boundaries

- $\quad$ stimulates higher education brand managers to rethink the perspective about brand identity as a dynamic construct with students having an important role as co-creators of the brand.

We characterise the brand identity prism in a higher consumer involvement by measuring the corporate brand identity. Measurement frameworks can be easily adopted for brand managers in order to develop strategies to fill in the gap between the ideal identity and the experienced one.

The organisation of this paper is as follows. In Section 2, we review the literature on branding, in Section 3 we develop the research hypotheses and a brief description of the methodology used to assess corporate brand identity using scale development. A brief description of the sample and the definitions of the used measures are also provided. Section 4 reports the results, summarises the model validity and applicability. In Section 5, there is a discussion of the results and finally, in Section 6 we draw a conclusion to this paper and provide directions for further research.

\section{Literature review}

According to Kapferer $(1986,2008,2012)$, who is a pioneer in the study of brand identity and a reference for every study in this area, the brand identity is divided into an internal part and an external part (see Figure 1). The internal part is responsible for decisions typically related to mission, values, strategy and brand structure. It is formed by three dimensions: culture, personality and self-image. The external part is formed by the elements defined by the interaction between the brand and the exterior: reflected consumer, relation consumer/brand and physical features. The external part is very important, especially in the case of corporate brands, owing to the fact that they are subject to constant interactions with different publics. 
Figure 1 Brand identity prism by Kapferer $(1986,2008,2012)$

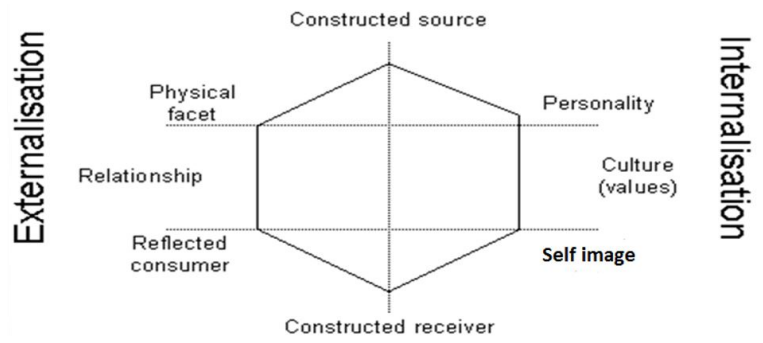

In order to define each dimension we adopt a holistic perspective reviewing literature on several fields of study like marketing, psychology and organisational studies.

'Brand personality' is an internal dimension, intangible and formed by the character and soul of the brand, that is, by the characteristics, traces of human personality that are relevant (Aaker, 1997; Kapferer, 1986, 2008), and likely to be applied to brands (Azoulay and Kapferer, 2003). According to Azoulay and Kapferer (2003), brand personality is defined by the following dimensions: agreeable, conscientious, innovative, peaceful, chic and maverick.

The branding concept of 'self-image' was proposed by Kapferer (1986, 2008, 2012) and it relates with how we want to be regarded by our pairs, by the people with whom we develop relationships. Therefore it is a 'relational self-concept'.

The dimension called 'reflected consumer' is an external and intangible dimension which reflects the way the consumer wishes to be regarded for 'using' a certain brand. It provides the consumer with a desirable model of identification (Kapferer, 1986, 2008, 2012). Even though it is an external dimension, brand managers should control the reflected consumer to avoid disagreement between the ideal identity and the experienced one.

The dimension called 'relation' is also external, with tangible and intangible areas. It defines the behaviour that identifies the brand and the way it interacts with its consumers (Kapferer, 1986, 2008, 2012).

One of the most cited research in this area is pursued by Fournier (1998). She characterises the relation between the consumer and the brand under a functional-emotional perspective. This approach is adopted by several authors in literature, e.g., de Chernatony (2006), Elliott and Percy (2007), Keller (1993), Martesen and Grønholdt (2004) and $\mathrm{Yu}$ and Dean (2001). The central idea is that consumers interact with brands not just because they permit functional benefits but because they simply like them. Fournier (1998) refers that it is necessary to dominate the meanings that a certain relation has with the consumers and the brands. Therefore, we consider it is necessary to find out what is the meaning of the relation between the consumers and the brand in a highly consumer involvement. Finally, the 'physical dimension' of brand identity is defined by Kapferer $(1986,2008,2012)$ as an exterior dimension that communicates the physical traits, colours, forms and qualities of the brand. The physical dimension is the skeleton of the brand and the starting point of any program of creation/development of brands (Kapferer, 1986, 2008, 2012). In the case of services, this component needs to be adapted. Although there is no physical component to be traded in higher education (except the final certificate...), there is always a physical space where the service takes place, which is related to physical components, for example, in the case 
of a higher education institution, the physical facet will be its logo, i.e., its image, as well as the quality of its schoolrooms, laboratories, library and other facilities, deans, lecturers and other staff. Once again we consider it is necessary to redefine this dimension.

The 'culture' dimension is internal, intangible; it integrates the brand in the organisation and is essential for brand differentiation (Kapferer, 1986, 2008, 2012). The author also refers that it is the cultural content of the brand identity that enables the transfer from organisation identity to brand identity, in the case of corporate brands. Therefore we argue that culture influences all the other dimensions of the prism (self-image, personality, reflected consumer, relation and physical). Culture is a dimension that moderates the analysis. In line with this we decided to adapt the study from Desphande and Webster (1989), who define organisational culture as the pattern of shared values and beliefs that help individuals understand organisational functioning and thus provide them with the norms and behaviour in the organisation. This definition is in line with the statements refereed by Kapferer (2000) who states that culture is the basic principle governing the brand in its outward side. Accordingly this research assumes that the culture of the brand is the perceived culture by the students/respondents about their university/institution. Therefore, it is possible that students of the same university/institution classify its culture differently, according to their different perceptions.

\section{Methodology and research hypotheses}

In order to select new multi-item scales to the dimensions that, as far as we know, had never been previously measured: self-image, reflected consumer, relation and physical, we developed a procedure of qualitative analysis summarised in Table 1 . This procedure considers the recommendations of Churchill (1979), Malhotra (1981), Laurent (2000) and of Clark and Watson (1995) who emphasise that good scale construction is an iterative process involving several periods of item writing, followed by conceptual and psychometric analysis.

Table 1 Procedure to develop the new multi-item scales

\begin{tabular}{|c|c|c|}
\hline \multicolumn{2}{|c|}{ Procedure to develop the multi-item scales } & \multirow{2}{*}{$\begin{array}{l}\text { Techniques and indicators } \\
\text { Literature review and discussion with experts }\end{array}$} \\
\hline 1 & Develop a theory & \\
\hline 2 & $\begin{array}{l}\text { Generate an initial pool of items to } \\
\text { each dimension/scale }\end{array}$ & $\begin{array}{l}\text { Theory, secondary data and } 13 \text { interviews to } \\
\text { lecturers and university managers, four focus } \\
\text { groups of students (bachelor, master and doctoral) }\end{array}$ \\
\hline 3 & $\begin{array}{l}\text { Select a reduced set of items based } \\
\text { on qualitative judgment }\end{array}$ & $\begin{array}{l}\text { Panel of ten experts (national and international, } \\
\text { academics and practitioners) }\end{array}$ \\
\hline 4 & $\begin{array}{l}\text { Collect data from a large } \\
\text { pre-test sample }\end{array}$ & Pre-test to a sample of 80 higher education students \\
\hline 5 & Perform statistical analysis & Reliability; factor analysis \\
\hline
\end{tabular}

Source: Adapted from Churchill (1979) and Malhotra (1981) 
Table 1 Procedure to develop the new multi-item scales (continued)

\begin{tabular}{lll}
\hline Procedure to develop the multi-item scales & Techniques and indicators \\
\hline 6 & Purify the measures & $\begin{array}{l}\text { Analysis of the results of the pre-test } \\
\text { sample and discussion with experts }\end{array}$ \\
7 & Collect data & $\begin{array}{l}\text { Survey to higher education students } \\
(235 \text { complete surveys) }\end{array}$ \\
$8 \quad \begin{array}{l}\text { Assess reliability and } \\
\text { unidimensionality }\end{array}$ & Chronbach's alpha and factor analysis \\
9 & Assess validity & $\begin{array}{l}\text { Construct (AVE and CR), discriminant } \\
\text { (comparison between the squared root of AVE and } \\
\text { the simple correlations) and nomological validity } \\
\text { (significant simple correlations examination) }\end{array}$ \\
& & Confirmatory factor analysis
\end{tabular}

Source: Adapted from Churchill (1979) and Malhotra (1981)

A brief summary of the scales and methodology used to find items is provided in Table 2 .

Table 2 Synthesis of the methodology used to find items for the scales

\begin{tabular}{|c|c|c|}
\hline Dimensions/scales & Adapted items & New items \\
\hline Culture & $\begin{array}{l}\text { Clan, adhocracy, hierarchical; } \\
\text { market adapted from } \\
\text { Deshpandé et al. (1993) }\end{array}$ & \\
\hline Personality & $\begin{array}{l}\text { Agreeable, conscientious, } \\
\text { innovative, peaceful, chic, } \\
\text { maverick adapted from } \\
\text { Azoulay and Kapferer (2003) }\end{array}$ & \\
\hline Self-image & & $\begin{array}{l}\text { Sources of influence: Kapferer } \\
(1986,2008)+\text { informants }+ \text { focus } \\
\text { groups of students }+ \text { experts }\end{array}$ \\
\hline Reflected consumer & & $\begin{array}{l}\text { Sources of influence: Kapferer } \\
(1986,2008)+\text { informants + focus } \\
\text { groups of students }+ \text { experts }\end{array}$ \\
\hline Relation & & $\begin{array}{c}\text { Sources of influence: Kapferer } \\
(1986,2008), \text { Fournier (1998), } \\
\text { Fournier and Alvarez (2012) + } \\
\text { informants + focus groups of } \\
\text { students + experts }\end{array}$ \\
\hline Physical & & $\begin{array}{c}\text { Sources of influence: Kapferer } \\
\text { (1986, 2008), de Chernatony } \\
\text { (1999) + informants + focus groups } \\
\text { of students + experts }\end{array}$ \\
\hline
\end{tabular}

The brand identity prism is empirically tested by developing and using a questionnaire in a sample of 235 students (see Table 3). Except in the case of the culture dimension, for all the measurement items, a five-point Liker scale was adopted, with anchors ranging from strongly disagree (1) to strongly agree (5), in a way this format better conforms to linear models, thus providing higher criterion validity (Weijters et al., 2010). 
Table 3 Summary of the research constructs and measures

\begin{tabular}{|c|c|c|}
\hline Construct & Initial full measured items & Source \\
\hline Culture & $\begin{array}{l}\text { Respondents are asked to distribute } 100 \text { points across four } \\
\text { descriptions }(\mathrm{A}, \mathrm{B}, \mathrm{C}, \mathrm{D}) \text { regarding four different kind of issues } \\
(1-\text { kind of organisation, } 2 \text { - leadership, } 3 \text { - what holds the } \\
\text { organisation together and } 4 \text { - what is important). }\end{array}$ & $\begin{array}{l}\text { Deshpande et al. } \\
\text { (1993) }\end{array}$ \\
\hline Personality & $\begin{array}{l}\text { If my university/institution were a person it would be: } \\
\text { P1 - agreeable; P2 - conscientious; P3 - innovative; } \\
\text { P4 - chic; P5 - peaceful; P6 - maverick. }\end{array}$ & $\begin{array}{c}\text { Azoulay and } \\
\text { Kapferer (2003) }\end{array}$ \\
\hline Self-image & $\begin{array}{l}\text { SI1 - better prepared for; SI } 2 \text { - proud for the certificate; } \\
\text { SI3 - very satisfied; SI } 4 \text { - makes me confident about the future; } \\
\text { SI5 - I consider myself part of an elite; SI6- I consider myself } \\
\text { an entrepreneur }\end{array}$ & New \\
\hline $\begin{array}{l}\text { Reflected } \\
\text { consumer }\end{array}$ & $\begin{array}{l}\text { I believe that the society in general considers the graduates by } \\
\text { my university/institution: RC1 - better prepared; RC } 2 \text { - more } \\
\text { capable of creating/innovating; RC } 3 \text { - successful professionals; } \\
\text { RC4 - professionals with high credibility; RC5 } 5 \text { - better than } \\
\text { others from other universities; RC } 6 \text { - amused/opened people. }\end{array}$ & New \\
\hline Relation & $\begin{array}{l}\text { I fell that the relation between my university/institution and me } \\
\text { is: R1 - friendly; R2 - respectful; R3 - trustable; R4 - motherly } \\
\text { R5 - close; R6 - fatherly }\end{array}$ & New \\
\hline Physical & $\begin{array}{l}\text { F1 - modern facilities; F2 - sophisticated facilities; } \\
\text { F3 - functional facilities; F4 - adequate facilities; } \\
\text { F5 - better facilities. }\end{array}$ & New \\
\hline
\end{tabular}

We propose three research hypotheses:

H1 The constructs personality, self-image, reflected consumer, relation and physical are correlated constructs.

$\mathrm{H} 2$ Cultures that are perceived as being performance oriented, adhocracy and market culture, develop more salient corporate brand identities.

H3 The constructs reflected-consumer, relation and physical are part of a higher dimension called external corporate brand identity.

The purpose of the first hypothesis is to validate the concept of brand identity using the dimensions of the prism defined by Kapferer $(1986,2008,2012)$ before including the brand culture as nominal variable. This research is used to validate the gathering of the other dimensions before adding the dimension culture (in $\mathrm{H} 2$ ).

The second hypothesis aims to validate the concept of brand identity using the six proposed dimensions as defined by Kapferer $(1986,2008)$. The previous five dimensions are scales (personality, self-image, reflected consumer, relation and physical) and the brand culture is a nominal variable used to identify the perceptions of the students regarding the brand identity of the corporate brand where they develop their studies. It is expected that this procedure identifies if the brand cultures perceived as being performance oriented are the ones that students have qualified as adhocracy and market culture known for developing more salient corporate brand identities. 
The third hypothesis aim is to confirm the concept of external brand identity as defined by Kapferer (1986, 2008, 2012): physical, relation and reflected consumer. This concept is very important because is through these dimensions that a corporate brand interact with its publics.

This research proposes a methodology to assess brand identity and its dimensions.

We use a two-step approach: first we estimate and test the fit and construct validity of the measurement model (Anderson and Gerbing, 1988; Hair et al., 2006; Ping, 2004; Jöreskog, 1993). If this model is satisfactory then the second step is to estimate and test the structural theory. Thus, the measurement model fit provides a basis for assessing the validity of the structural theory (Hair et al., 2006).

Our sample is compounded by 235 individuals. According to what has been stated and Hair et al.'s (2006) suggestions for a sample of 250 individual or less, with items between 12 and 30, we followed the guidelines:

- $\mathrm{CMIN} / \mathrm{DF}<2.00$ (Byrne, 2010)

- $\quad$ CFI* $^{*} 0.95$ (Hair et al., 2006; Byrne, 2010; Ping, 2004)

- $\quad$ RMSEA < 0.08 (Hair et al., 2006; Hu and Bentler, 1999; Bentler, 1990) with CFI $\geq 0.95$ (Hair et al., 2006).

$\mathrm{Hu}$ and Bentler (1999), Bentler (1990) and Browne and Cudeck (1993) argue that satisfactory model fits are indicated by non-significant chi-square tests, RMSEA value $\leq$ 0.08 and $\mathrm{CFI} \geq 0.90$. Nevertheless we opted for the mentioned criteria because we believe that a measurement of a very important theory demands a conservative approach.

Following the procedures to test the second-order factors to the corporate brand identity and the external corporate brand identity, we divide this research in two parts.

Then, we test the second-order factor to the external part of the brand identity to validate this concept proposed by Kapferer $(1986,2008,2012)$ which is very important in the context of corporate brands because of the interactions with the stakeholders, particularly, the consumers.

Each of these dimensions is in itself a factor reflecting multiple item scales to assess the second-order factor of the corporate brand identity and of the corporate external brand identity as we intend to demonstrate.

MacKenzie et al. (2005) claim that the use of higher-order factor allows more theoretical parsimony and reduces model complexity. For further details on second-order models, see also Bagozzi and Heatherton (1994), Gerbing and Anderson (1984), Gerbing et al. (1994), Hunter and Gerbing (1982), Jarvis et al. (2003), Law et al. (1998) and Netemeyer et al. (2003).

Based on the referred considerations the individual dimensions of the brand identity prism are first-order factors, and corporate brand identity the second-order factor reflecting a higher level of abstraction. We followed the guidelines detailed by Bagozzi et al. (1991) to test the second order confirmatory factor analysis (SOCFA) model (Anderson, 1987).

Furthermore we tested the plausibility of the higher-order factor model for construct validity and goodness-of-fit (GOF). Firstly we estimated a first-order measurement model, analysing construct validity and GOF indices. Only then did we estimate a second-order factor model and analyse construct and nomological validity, because higher-order factors should be examined for criterion validity. A primary validation 
criterion turns out to be how well the higher-order factor explains the theoretically related constructs.

We used Amos software (21st version) (Arbuckle, 2010) and maximum likelihood (ML) estimation method to conduct this study, CFA to assess the reliability and construct validity (convergent and discriminant).

In the next section results will be provided.

\section{Results}

To test the first hypothesis we developed the measurement model to the five factor model. The results provided insights to model re-specification. Therefore, we decided to drop F5, P1 and P5. The psychometric properties of the first order constructs are summarised in Table 4.

Table 4 Psychometric properties for the first-order constructs

\begin{tabular}{|c|c|c|c|c|c|c|}
\hline Measured items & Factor loadings $\lambda_{1}$ & $\overline{\sum^{a)}}$ & Delta) & $A V E$ & $C R$ & Cronbach's $\alpha$ \\
\hline Tangible physical & & & & 0.79 & 0.92 & 0.877 \\
\hline $\mathrm{F} 1$ & 0.870 & & 0.130 & & & \\
\hline F2 & 0.937 & & 0.063 & & & \\
\hline F3 & 0.674 & & 0.326 & & & \\
\hline $\mathrm{F} 4$ & 0.666 & 3.174 & 0.334 & & & \\
\hline Relation & & & & 0.68 & 0.88 & 0.790 \\
\hline R1 & 0.609 & & 0.391 & & & \\
\hline $\mathrm{R} 2$ & 0.818 & & 0.182 & & & \\
\hline R3 & 0.868 & & 0.132 & & & \\
\hline $\mathrm{R} 4$ & 0.516 & & 0.484 & & & \\
\hline R5 & 0.599 & 3.410 & 0.401 & & & \\
\hline Reflected-consumer & & & & 0.82 & 0.94 & 0.878 \\
\hline $\mathrm{RC} 1$ & 0.722 & & 0.278 & & & \\
\hline $\mathrm{RC} 2$ & 0.785 & & 0.215 & & & \\
\hline $\mathrm{RC} 3$ & 0.856 & & 0.144 & & & \\
\hline $\mathrm{RC} 4$ & 0.913 & 3.276 & 0.087 & & & \\
\hline Self-image & & & & 0.79 & 0.92 & 0.796 \\
\hline SI1 & 0.797 & & 0.203 & & & \\
\hline SI2 & 0.730 & & 0.270 & & & \\
\hline SI3 & 0.825 & & 0.175 & & & \\
\hline SI4 & 0.811 & 3.163 & 0.189 & & & \\
\hline Personality & & & & 0.70 & 0.83 & 0.731 \\
\hline $\mathrm{P} 2$ & 0.727 & & 0.273 & & & \\
\hline P3 & 0.669 & & 0.331 & & & \\
\hline P4 & 0.693 & 2.089 & 0.307 & & & \\
\hline
\end{tabular}

Notes: ${ }^{\text {a) }}$ Sum of the factor loadings.

b) Delta is a measure that is used to calculate the construct reliability (CR) and the formula do obtain it is $1-\lambda$. 
In assessing the re-specified five factor first-order measurement model we ran CFA not only to test the overall fit but also to test the validity of the measures. As shown in Table 4, the results supported convergent validity for all measures: all estimated factor loadings of the items are above the threshold of 0.5 and were all significant $(p<0.001)$ exceeding the statistical significance level accepted in this study. Standardised residuals suggest no modification: all residuals are below 2.58 (cutoff value according to Jöreskog and Sörbom, 2001) suggesting no major problems with items covariance's discrepancy.

The overall model fit was satisfactory: $\chi^{2}(156)=251.518 ; \mathrm{p}=.000$, CMIN/DF was 1.612, which is less than the maximum of 2 (Byrne, 1989, 2010), and the CFI, and the RMSEA were satisfactory ( 0.965 and 0.051 , respectively). Using the $90 \%$ confidence interval we concluded the true value of RMSEA is between 0.039 and 0.063 (even the upper bound is lower than the threshold of 0.08) which is an acceptable fit.

From the examination of the correlation estimates we can conclude they are high but it seems also that there is a lack of discriminant validity between personality and self-image. Yet, if we round the values to three decimals we can observe that the square root of the AVE from personality (0.834) is higher than the correlation between personalities and self-image (0.826). Therefore, we can conclude that there is discriminant validity in the sense of Fornell and Larcker (1981).

In line with these findings we can accept the first hypothesis and conclude that the constructs personality, self-image, reflected consumer, relation and physical are correlated meaning that we can know include the nominal variable culture and verify if cultures perceived as being performance oriented develop more salient brand identities. This corporate brand identity salience is measured by the model fit.

This research assumes that the culture of the brand is the students ' perceived culture about their university/institution. This perception is identified by using an adapted scale to measure organisational culture proposed by Desphande et al. (1993). Accordingly, the dimension culture is then converted into a nominal variable identifying the perceived culture by each respondent.

According to Desphande et al. (1993), adhocracy and market cultures develop higher levels of performance and oppositely, clan and hierarchical cultures develop smaller levels of organisational performance. In this study, it is expected that cultures perceived as being performance oriented (market and adhocracy cultures) develop more salient brand identities (measured by the model fit) than cultures perceived as being less performance oriented (clan and hierarchical cultures).

To test the second hypotheses we divided our 235 individuals sample in two groups (136 and 99 individuals) according with the findings of Desphande et al. (1993) and ran a CFA to each group.

Figure 2 depicts the second-order factor for the corporate brand identity according to the proposed model by Kapferer $(1986,2008,2012)$. The model that we defined includes 'culture' as a moderator of the rest of the five dimensions proposed by the author. This finding is very interesting for it was never mentioned in previous studies regarding brand identity. 
Figure 2 Corporate brand identity moderated by 'culture' (see online version for colours)

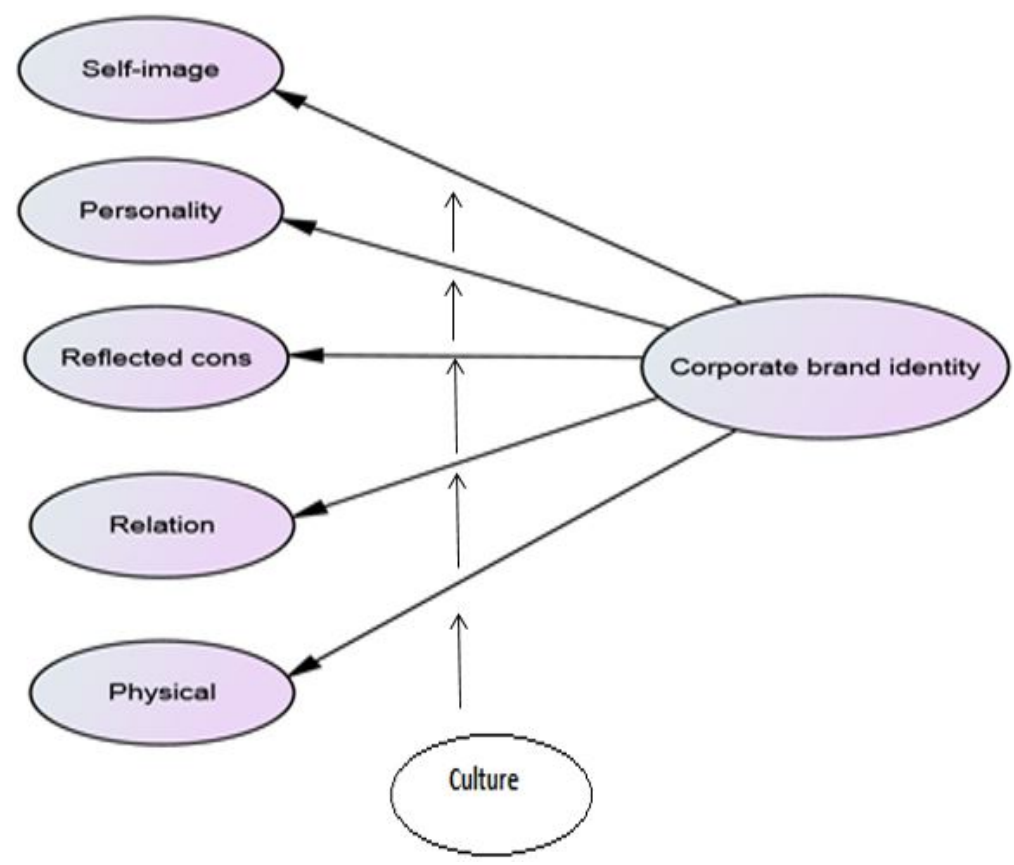

Figure 3 Second order factor for external corporate brand identity (see online version for colours)

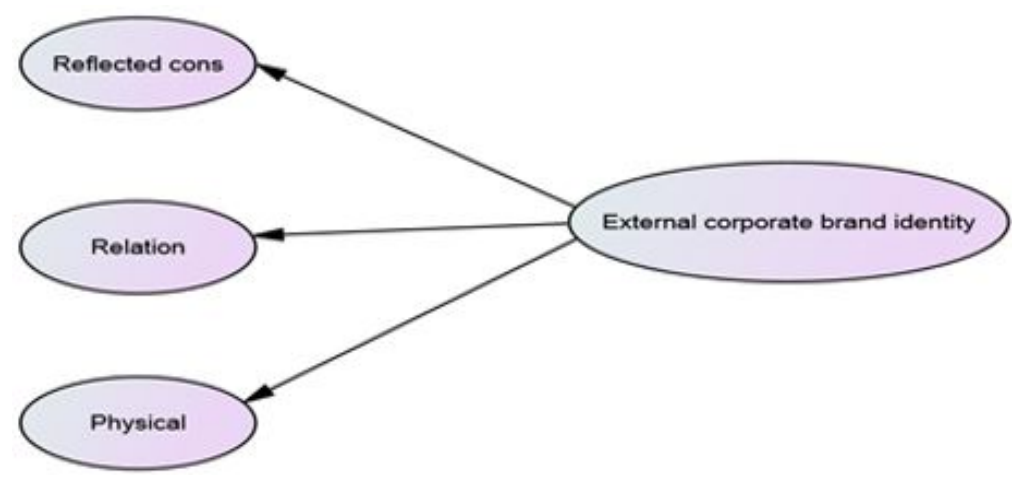

The analysis includes the six dimensions of the brand identity as defined by Kapferer (1986, 2008, 2012), five of which are scales ('physical', 'relation', 'reflected consumer', 'personality' and 'self-image') and 'culture' is a nominal variable that is a moderator of the model.

The results (see Table 5) show that, according to the theory, the group formed by market and adhocracy perceived culture fits better than the group formed by the clan and hierarchical perceived cultures, having the last ones an unacceptable fit regarding the upper bound of the RMSEA using the $90 \%$ confidence interval. 
Table 5 Comparison of the first order constructs for brand identity considering the perceived culture

\begin{tabular}{|c|c|c|c|c|c|c|}
\hline & $\chi^{2}$ & $D F$ & $p$ & $C M I N / D F$ & $C F I$ & RMSEA \\
\hline $\begin{array}{l}\text { Performance-oriented } \\
\text { cultures }(\mathrm{N}=136)\end{array}$ & 239.981 & 158 & 0.000 & 1.519 & 0.942 & $\begin{array}{c}0.062 \\
{[0.046 ; 0.077]}\end{array}$ \\
\hline $\begin{array}{l}\text { Less performance-oriented } \\
\text { cultures }(\mathrm{N}=99)\end{array}$ & 275.839 & 159 & 0.000 & 1.735 & 0.912 & $\begin{array}{c}0.087 \\
{[0.069 ; 0.103]}\end{array}$ \\
\hline
\end{tabular}

The first order-factor for brand identity formed by the group that is perceived as being performance oriented, in spite of revealing construct validity, it reveals problems related to discriminant validity between self-image and personality.

Even knowing that the first order constructs for brand identity considering the perceived culture (six dimensions as proposed by Kapferer: 'physical', 'relation', 'reflected consumer', 'personality', 'self-image' and 'culture') did not reveal discriminant validity in the case of the performance oriented cultures, we developed the second order model and compared it with the second-order model without the dimension 'self-image'. The results are in Table 6.

Table 6 Comparison of the second order constructs for brand identity considering the perceived culture

\begin{tabular}{|c|c|c|c|c|c|c|}
\hline $\begin{array}{l}\text { Performance-oriented } \\
\text { cultures }\end{array}$ & $\chi^{2}$ & $D F$ & $p$ & $C M I N / D F$ & CFI & $R M S E A$ \\
\hline $\begin{array}{l}\text { Six dimensions (Kapferer, } \\
1986,2008,2012 \text { ) }\end{array}$ & 249.908 & 163 & 0.000 & 1.533 & 0.939 & $\begin{array}{c}0.063 \\
{[0.47 ; 0.078]}\end{array}$ \\
\hline $\begin{array}{l}\text { Five dimensions } \\
\text { (without self-image) }\end{array}$ & 141.882 & 98 & 0.003 & 1.448 & 0.955 & $\begin{array}{c}0.058 \\
{[0.035 ; 0.078]}\end{array}$ \\
\hline
\end{tabular}

Although the model of the five dimensions fits relatively better, both models reveal very acceptable fits. Yet, we must recall that the proposed model for the six dimensions did not reveal discriminant validity.

Taking in attention the limitations of the model, we can accept the second hypothesis and conclude that cultures that are perceived as being performance oriented (market and adhocracy) develop more salient corporate brand identities.

According to Kapferer (1996, 2008, 2012), brand identity is divided into an internal part (culture, personality and self-image) and an external part (relation, reflected consumer and physical). The external part is very important, especially in the case of corporate brands, owing to the fact that they are subject to constant interactions with different publics. In line with this, we assessed the first-order factor to the corporate external brand identity by running a CFA not only to test the overall fit but also to test the validity of the measures. Results are provided in Tables 7 and 8.

We assessed the second-order factor structure in order to determine the plausibility of the second-order model of the three factor structure (relation, reflected consumer and tangible physical). The results are summarised in Table 9. 
Table 7 First order construct for the external part of the corporate brand identity

\begin{tabular}{|c|c|c|c|c|c|c|c|}
\hline \multirow{2}{*}{\multicolumn{2}{|c|}{ Three factor }} & $\chi^{2}$ & $D F$ & $p$ & $C M I N / D F$ & CFI & RMSEA \\
\hline & & 82.685 & 59 & 0.023 & 1.401 & 0.985 & 0.041 \\
\hline \multirow{2}{*}{ Table 8} & \multicolumn{7}{|c|}{ Construct and discriminant validity } \\
\hline & & \multicolumn{3}{|c|}{ Tangible physical } & Relation & & eflected consumer \\
\hline \multicolumn{8}{|c|}{ Construct validity: } \\
\hline \multicolumn{2}{|c|}{ AVE } & \multicolumn{2}{|c|}{0.79} & \multicolumn{2}{|r|}{0.68} & & 0.79 \\
\hline \multirow[t]{2}{*}{$\mathrm{CR}$} & & \multicolumn{2}{|c|}{0.92} & \multicolumn{2}{|r|}{0.88} & & 0.92 \\
\hline & & \multicolumn{2}{|c|}{ Relation } & & gible physical & & eflected consumer \\
\hline \multicolumn{8}{|c|}{ Discriminant validity: } \\
\hline \multicolumn{2}{|c|}{ Relation } & \multicolumn{2}{|c|}{0.82} & & & & \\
\hline \multicolumn{2}{|c|}{ Tangible physical } & \multicolumn{2}{|c|}{0.31} & \multicolumn{2}{|r|}{0.89} & & \\
\hline \multicolumn{2}{|c|}{ Reflected consumer } & \multicolumn{2}{|c|}{0.63} & \multicolumn{2}{|r|}{0.42} & & 0.89 \\
\hline
\end{tabular}

Table 9 Second-order factors for external brand identity

\begin{tabular}{lcccccccc}
\hline Model & $\chi^{2}$ & $D F$ & $p$ & $C M I N / D F$ & $C F I$ & $R M S E A$ & $A V E$ & $C R$ \\
\hline Three factor & 52.685 & 59 & 0.023 & 1.401 & 0.985 & 0.041 & 0.69 & 0.82 \\
& & & & & & {$[0.016 ; 0.061]$} & & \\
\hline
\end{tabular}

We can conclude that for a sample like this $(235<250)$ the results fulfil Hair's guidelines (Hair et al., 2006) and the second order factor reveals an AVE of $0.69(>0.5)$ and a CR of $0.82(>0.7)$ exceeding the acceptable values.

We can conclude that, according to theory, there is a second-order factor for the corporate external brand identity formed by three factors: relation, reflected consumer and tangible physical. Therefore, we can accept the third hypothesis and conclude that the constructs reflected-consumer, relation and physical are part of a higher dimension called external identity.

\section{Discussion}

The measurement of corporate brand identity is scarce in brand management literature. The results of this research have an important meaning because they prove that the brand identity field can be investigated using quantitative methodologies, especially if a qualitative procedure had been developed previously. The use of both methodologies in different stages of the research was considered very enriching. We must highlight that this research is, as far as our knowledge concerned, the first measurement of the brand identity prism by Kapferer (1986, 2008, 2012).

Because we could not find adequate scales in branding literature, four new scales came out of this research to characterise the brand identity prism: self-image, reflected consumer, relation and physical. The scales were developed through a sample of engineering higher education students, following a procedure that involved literature review and the use of informants, focus groups and experts in the area. The other two dimensions: culture and personality were adapted from previous studies under a holistic 
approach. The culture dimension was adapted to the services context, from Desphande et al. (1993). These authors developed four types of organisational culture (clan, hierarchical, adhocracy and market culture) that were used here. This inclusion and adaptation to the higher education context turned out to be rather innovative in the branding area contributing to an approach between fields of study.

The research development found a new perspective of the physical dimension. The finding regarding the named intangible physical was mentioned in the description of the Physical dimension developed by Kapferer (1986, 2008, 2012). The author states that the physical dimension is formed by features like the logo, buildings... but also the qualities and other intangible features of the brand. Therefore, it was expected that the intangible features should be included in the physical dimension as defined by the author. Nevertheless, as the methodology selected to do this research demanded unidimensionality, the physical dimension had to be divided in two scales, one more connected to tangible features and another to intangible features. This dimension was never particularised in previous studies. Nevertheless it was always present in the physical dimension defined by Jean Noel Kapferer. This scale, although revealed validity and reliability, did not show enough discriminant validity to be considered a single differentiated factor. We are convinced that this dimension could be differentiated in other samples.

The model showed robustness even using five of the original six dimensions proposed by Kapferer (1986, 2008), without considering the dimension 'culture' which was used afterwards as a moderator of the analysis.

The brand identity model as defined by Kapferer $(1986,2008,2012)$ is defined by six dimensions ('physical', 'relation', 'reflected consumer', 'personality' and 'self-image') and 'culture' is a nominal variable that moderates the analysis. We found that the 'culture' moderates the analysis of the brand identity in a corporate brand context by influencing all the other dimensions. It was found that cultures perceived as being performance oriented, adhocracy and market culture, develop more salient corporate brand identities. This finding is considered very important because the authors' could not find it mentioned in previous literature regarding brand identity.

This research gives a step forward and concludes that the brand culture dimension influences all the other dimensions; therefore, it is a development of the theory proposed by Kapferer (2008).

Regarding the external part of the corporate brand identity the research gave important insights regarding the theory proposed by Kapferer (1986, 2008, 2012) concluding that the brand identity prism is formed by an external part formed by the dimensions more exposed to interaction with the publics: reflected consumer, (tangible) physical and relation. These are the dimensions that are more connected to corporate brands and therefore they were very important to this study. The selected higher education universities/institutions developed their identities acting like corporate brands. Therefore it was important to find whether there is a common identity coming out of the engineering higher education context, known for their salient and very characteristic identities.

The results confirm the brand identity theory proposed by Kapferer, in a way that was never tested before. The brand identity prism (with the six proposed dimensions) and the external part of the brand identity were measured by the first time and the results confirm one of the most developed and cited theory in the branding literature. 
In the next section we draw a final conclusion regarding this research, justify it in the brand management field and suggest future experiments.

\section{Conclusions and further research}

Identity studies are mostly developed under a qualitative analysis. This came about as an opportunity to develop a measurement analysis of corporate brand identity. For that purpose we used the brand identity model by Jean Noel Kapferer. We should highlight that this research is, as far as our knowledge concerned, the first measurement of the brand identity prism.

Services are very particular, mainly higher education, because of its particular characteristics regarding the involvement of the consumers. Students are external stakeholders (consumers) but also internal and therefore they have a main role in delivering the brand promise of their university/institution.

The culture dimension was included in this research. Using the findings revealed by Desphande et al. (1993) we were able to identify the perceived culture by each student regarding their university/institution. In line with this, we demonstrated that cultures perceived as being performance oriented develop more salient corporate brand identities.

Corporate brands are much exposed to interaction of the different publics. Therefore, in line with the proposed definition of external brand identity by Kapferer $(1986,2008$, 2012), we measured the external corporate brand identity. This research concludes quantitatively that the three factors: relation, reflected consumer and tangible physical make sense together and that there is a higher external dimension formed by these three factors.

Future analysis and empirical research must be developed namely the testing of this questionnaire in another samples in order to improve the measures and to generalisation.

\section{References}

Aaker, D.A. (1996) Building Strong Brands, Free Press, New York.

Aaker, J.L. (1997) 'Dimensions of brand personality', Journal of Marketing Research, Vol. 34, No. 3, pp.347-356.

Anderson, J.C. (1987) 'An approach to confirmatory measurement and structural equation modelling of organizational properties', Management Science, Vol. 33, No. 4, pp.525-541.

Anderson, J.C. and Gerbing, D.W. (1988) 'Structural equation modelling in practice: a review and recommended two-step approach', Psychological Bulletin, Vol. 103, No. 3, pp.411-423.

Arbuckle, J.L. (2010) Amos (Version 18), SPSS Inc., Chicago, IL.

Azoulay, A. and Kapferer, J-N. (2003) 'Do brand personality scales really measure brand personality?', Brand Management, Vol. 11, No. 2, pp.143-55.

Bagozzi, R.P. and Heatherton, T.F. (1994) 'A general approach to representing multifaceted personality constructs: application to self esteem', Structural Equation Modelling, Vol. 1, No. 1, pp.35- 67.

Bagozzi, R.P., Yi, Y. and Philips, L.W. (1991) 'Assessing construct validity in organizational research', Administrative Science Quarterly, Vol. 36, No. 3, pp.421-458.

Balmer, J.M.T. (1998) 'Corporate identity and the advent of corporate marketing', Journal of Marketing Management, Vol. 14, No. 8, pp.963-996. 
Balmer, J.M.T. and Soenen, G.B. (1999) 'The acid test of corporate identity management', Journal of Marketing Management, Vol. 15, Nos. 1-3, pp.69-92.

Bentler, P.M. (1990) 'Comparative fit indexes in structural models', Psychological Bulletin, Vol. 107, No. 2, pp.238-246.

Browne, M.W. and Cudeck, R. (1993) 'Alternative ways of assessing model fit', in Bollen, K.A. and Long, J.S. (Eds.): Testing Structural Equation Models, pp. 136-162, Sage, Newbury Park, CA.

Burmann, C.J-B.M. and Riley, N. (2009) 'Towards an identity-based brand equity model', Journal of Business Research, Vol. 62, No. 3, pp.390-397.

Byrne, B.M. (2010) Structural Equation Modelling with AMOS: Basic Concepts, Applications, and Programming, Routledge, Taylor and Francis Group, NY.

Churchill, G.A. (1979) 'A paradigm for developing better measures of marketing constructs', Journal of Marketing Research, Vol. XVI, No. 1, pp.64-73.

Clark, L.A. and Watson, D. (1995) 'Constructing validity: basic issues in objective scale development', Psychological Assessment, Vol. 7, No. 3, pp.309-319.

Coleman, D., de Chernatony, L. and Christodoulides, G. (2011) 'B2B service brand identity: scale development and validation', Industrial Marketing Management, Vol. 40, No. 7, pp.1063-1071.

Cornelissen, J.P., Lock, A.R. and Gardner, H. (2001) 'The organisation of external communication disciplines: an integrative framework of dimensions and determinants', International Journal of Advertising, Vol. 20, No. 1, pp.67-88

de Chernatony, L. (1999) 'Brand management through narrowing the gap between brand identity and brand reputation', Journal of Marketing Management, Vol. 15, Nos. 1/3, pp.157-179.

de Chernatony, L. (2006) From Brand Vision to Brand Evaluation: The Strategic Process of Growing and Strengthening Brands, 2nd ed., Butterworth - Heinemann (Elsevier), Burlington, USA.

de Chernatony, L. and Segal-Horn, S. (2001) 'Building on services characteristics to develop successful services brands', Journal of Marketing Management, Vol. 17, Nos. 7/8, pp.645-669.

Desphande, R., Farley, J.U. and Webster Jr., F.E. (1993) 'Corporate culture, customer orientation, and innovativeness in Japanese firms: a quadrad analysis', Journal of Marketing, Vol. 57, No. 1, pp.23-37.

Deshpande, R. and Webster Jr., F.E. (1989) 'Organizational culture and marketing: defining the research agenda', The Journal of Marketing, January, Vol. 53, No. 1, pp.3-15.

Elliott, R.H. and Percy, L. (2007) Strategic Brand Management, Oxford University Press, New York.

Fornell, C. and Larcker, D.F. (1981) 'Evaluating structural equation models with unobservable variables and measurement error', Journal of Marketing Research, Vol. 18, No. 1, pp.39-50.

Fournier, S. (1998) 'Consumers and their brands', Journal of Consumer Research, Vol. 24, No. 4, pp.343-373.

Fournier, S. and Alvarez, C. (2012) 'Brands as relationship partners: warmth, competence, and in-between', Journal of Consumer Psychology, Vol. 22, No. 2, pp.177-185.

Gerbing, D.W. and Anderson, J.C. (1988) 'An updated paradigm for scale development incorporating unidimensionality and its assessment', Journal of Marketing Research, Vol. 25, No. 2, pp.186-192.

Gerbing, D.W., Hamilton, J.G. and Freeman, E.B. (1994) 'A large-scale second-order structural equation model of the influence of management participation on organizational planning benefits', Journal of Management, Vol. 20, No. 4, pp.859-885. 
Hair, J.F., Black, W.C., Babin, B.J., Anderson, R.E. and Tatham, R.L. (2006) Multivariate Data Analysis, Prentice-Hall, NJ.

Hu, L-T. and Bentler, P.M. (1999) 'Cutoff criteria for fit indexes in covariance structure analysis: conventional criteria versus new alternatives', Structural Equation Modelling, Vol. 6, No 1, pp.1-55.

Hunter, J.E. and Gerbing, D.W. (1982) 'Unidimensional measurement, second-order factor analysis and causal models', in Staw, B.M. and Cummings, L.L. (Eds.): Research in Organizational Behaviour, Vol. 4, JAI Press, Greenwich, CT.

Jarvis, D., MacKenzie, S. and Podsakoff, P. (2003) 'A critical review of construct indicators and measurement model misspecification in marketing and consumer research', Journal of Consumer Research, Vol. 30, No 3, pp.199-218.

Jöreskog, K. and Sörbom, D. (2001) LISREL 8: User's Reference Guide, 2nd ed., Scientific Software International, Chicago.

Jöreskog, K.G. (1993) Testing Structural Equation Models, Bollen, K.A. and Long, J.S. (Eds.), SAGE Publications, Newbury Park, CA.

Kapferer, J-N. (1986) 'Beyond positioning, retailer's identity', Esomar Seminar Proceedings, Brussels, 4-6 June, pp.167-76.

Kapferer, J-N. (2000) Strategic Brand Management - Creating and Sustaining Brand Equity Long Term, 1st ed., pp.90-119, Kogan Page Publishers, UK.

Kapferer, J-N. (2008) The New Strategic Brand Management - Creating and Sustaining Brand Equity Long Term, 4th ed., Kogan Page, UK.

Kapferer, J-N. (2012) The New Strategic Brand Management: Advanced Insights and Strategic Thinking, Kogan Page Publishers, UK.

Keller, K.L. (1993) 'Conceptualizing, measuring and managing customer-based brand equity', Journal of Marketing, Vol. 57, No. 1, pp.1-22.

Laurent, G. (2000) 'Improving the external validity of marketing models: a plea for more qualitative input', International Journal of Research in Marketing, Vol. 17, Nos. 2/3, pp.177-182.

Law, K.S., Wong, C. and Mobley, W.H. (1998) 'Toward a taxonomy of multidimensional constructs', Academy of Management Review, Vol. 23, No. 4, pp.741-755.

MacKenzie, S.B., Podsakoff, P.M. and Jarvis, C.B. (2005) 'The problem of measurement model misspecification in behavioral and organizational research and some recommended solutions', Journal of Applied Psychology, Vol. 90, No. 4, pp.710-730.

Malhotra, N.K. (1981) 'A scale to measure self-concepts, person concepts, and product concepts' Journal of Marketing Research, Vol. XVIII, No. 4, pp.456-464.

Martesen, A. and Grønholdt, L. (2004) 'Building brand equity: a customer-based modelling approach', Journal of Management Systems, Vol. 16, No. 3, pp.37-51.

Meleware, T.C. (2003) 'Determinants of the corporate identity construct: a review of the literature', Journal of Marketing Communications, Vol. 9, No. 4, pp.195-220.

Netemeyer, R.G., Bearden, W.O. and Sharma, S. (2003) Scaling Procedures: Issues and Applications, Sage Publications, Thousand Oaks, CA.

Ping, R.A. (2004) 'On assuring valid measures for theoretical models using survey data', Journal of Business Research, Vol. 57, No 2, pp.125-141.

Semprini, A. (2006) Marca Pós Moderna, Edição das Letras, São Paulo (Brasil).

Silveira, C.d, Lages, C. and Simões, C. (2013) 'Reconceptualizing brand identity in a dynamic environment', Journal of Business Research, Vol. 66, No. 1, pp.28-36.

Simões, C., Dibb, S. and Fisk, R.P. (2005) 'Managing corporate identity: an internal perspective', Journal of the Academy of Marketing Science, Vol. 33, No. 2, pp.153-168. 
Suvatjis, J.Y. and de Chernatony, L (2005) 'Corporate identity modelling: a review and presentation of a new multidimensional model', Journal of Marketing Management, Vol. 21, No. 7, pp.809-834, doi: 10.1362/026725705774538480.

Upshaw, L. (1995) Building Brand Identity, John Wiley, New York.

Weijters, B., Cabooter, E. and Schillewaert, N. (2010) 'The effect of rating scale format on response styles: the number of response categories and response category labels', International Journal of Research in Marketing, Vol. 27, No. 3, pp.236-247.

Yu, Y-T. and Dean, A. (2001) 'The contribution of emotional satisfaction to consumer loyalty', International Journal of Service Industry Management, Vol. 12, No. 3, pp.234-250. 